\title{
MINDANAO CONFLICT AND ISLAMIC REVIVALISM: THE MORO ISLAMIC LIBERATION FRONT'S APPROACH
}

\author{
Marjanie Salic Macasalong*
}

\begin{abstract}
The Moros, or Muslims in the southern part of the Philippines, have struggled for self-determination since the $16^{\text {th }}$ century, when Spanish colonial domination arrived in the islands that came to be known as the Philippines. Centuries later, when "the Philippines" gained complete independence from an imperial United States, the newly independent nation inherited longstanding grievances of the Moro people, who continued their armed-struggle to regain their right for self-determination, through long and drawn out warfare that involved the whole population of the Philippines. This conflict was never simply about the Manila government and Moro rebel groups, but was always a complex, deep-rooted and multifaceted one that began during Spanish colonisation. The Moro Islamic Liberation Front (MILF), is today a mass-based organisation in Mindanao, having organised millions of people from all walks of life through a powerful social justice program with an emphasis on Islam as the ultimate goal. It advocates liberating the Moro homeland through establishing Islamic Sharia in the region. The MILF's revivalist and Islamisation programs have shored up the notion of self-reliance among the "Bangsamoro" people and planted an Islamic way of life in their communities and religious, social, economic, and military structures, through schools, madrasah, mosques, sharia courts, and multi-purpose cooperatives. The way forward today lies in the recognition of the legitimate rights of the Moros for self-determination and, from the Moros, respect for the territorial integrity of the Philippines.
\end{abstract}

\section{Introduction}

Desire for peace is common in every society, yet history has been marked with conflicts from time immemorial. Currently, the United Nations' Charter promulgates the idea of self-determination with the aim of achieving peace if a particular nation is given the right to form a state and manage its own affairs without external interference. The Moros ${ }^{1}$ in the southern part of the Philippines have been fighting for self-determination and their identity for more than four hundred years. Beginning in the $16^{\text {th }}$ century, when the Spanish colonial power first set foot in what is now known as the Philippines, ${ }^{2}$ the Moros fought to defend their legitimate rights as an independent nation.

When the Philippines gained complete independence from the United States, it inherited the long-standing grievances of the Moros. Never tiring of fighting 
for their rights, the Moros employed armed struggle in order to regain their right to self-determination. This struggle, however, resulted in more vigorous fighting that involved the whole population of the Philippines. The conflict is not merely between the Manila government and Moro rebel groups; rather it is a complex, deep-rooted and multifaceted one that began during Spanish colonisation.

\section{The Sultanate Era}

Islam reached the inhabitants of the islands of the Philippines, introduced to the local populace by Muslim individuals, Arab traders and missionaries, and spread in a gradual manner. It was already flourishing in the Islands long before Spanishbacked Christianisation came in the middle of the $16^{\text {th }}$ century. The Moros during that time were already active in both domestic and international trade. It was reported that, as early as the $10^{\text {th }}$ century, "there is evidence that Arab ships, or rather, ships captained by Arabs, had reached China from some Island in the Philippines during the tenth century," ${ }^{3}$ and that Moro boats carried trade goods as far as the Persian Gulf and New Guinea. ${ }^{4}$

The Islamisation of southern Philippines was part of the general spread of Islam throughout the Malay world. Islam came first to what are now known as Indonesia and Malaysia before reaching the Sulu and Mindanao islands. The earliest report of the adoption of Islam by local Southeast Asians, particularly in the area of Sumatra in Indonesia and Muslim principalities in Malay world, was that of Venetian traveller Marco Polo in the late $13^{\text {th }}$ century. ${ }^{5}$ Since these areas are close to the Philippines, specifically Sulu, and because they were connected through trade, it is not unreasonable to assume that Arab traders and missionaries learned of Sulu around that time.

According to Majul's authoritative book, Muslims in the Philippines, when various Arab missionaries came to Sulu during the last quarter of the $13^{\text {th }}$ century, a Muslim community was already existing in Sulu. ${ }^{6}$ The account of Che Man went further to claim that the Chinese sources dating from Yuan Dynasty (12801368) recorded trade activities between China and Sulu because the latter was a commercial centre that even Arab, Thai, Indonesian, and Indian traders used to visit. $^{7}$

However, the establishment of the Islamic Sultanate, the penetration of Islam to the coastal and mountainous areas and the establishment of organised religious institutions, were only evident during the middle of the $15^{\text {th }}$ century, ${ }^{8}$ with the arrival of Muslim Malays from Sumatra. This stage saw the rise of Rajah Baginda, a prince from Sumatra who was widely credited for establishing the first Muslim dynasty in the island. He married a daughter of a Muslim tribal chief in Sulu that enabled him to easily consolidate power in the community. 
This existence of a Muslim ruler guaranteed the preservation of the work of the previous missionaries and paved the way for other locals to embrace Islam.

In the specific area of Maguindanao, it was recorded in the written Maguindanao genealogy that a certain Sharif Awliya came to the area in the middle of the $15^{\text {th }}$ century, married there, begot a daughter, and introduced Islam to the locals. However, Sarip Muhammad Sarip Kabungsuwan, the offspring of the princess of the Johor royal family and a direct descendant of the Prophet Muhammad, (pbuh), was widely credited with strengthening Islam in the area. ${ }^{9}$

In the area of Lanao, which is just adjacent to Maguindanao and where the Maranaos and Iranuns dwell, it was reported that Islam was introduced to the people through marriage alliances. The Iranun datus ${ }^{10}$ was reported to have intermarried with the Maguindanao datus. In the case of the Maranao datus, it was also reported that people of Butig intermarried with the people of Malabang, a place where Kabungsuwan had first landed and founded Islam. ${ }^{11}$ It is reasonable then to infer that Islam had been introduced to the Maranao datus through such marriage alliances, though other accounts suggest that Kabungsuwan himself had gone to the area and converted the locals. ${ }^{12}$ Subsequently, the Sultanate of Buayan and the Pat a Pangampong ko Ranao (Confederation of the Four Lakebased Emirates) in Lanao were established. Kabungsuan also spread Islam to the other parts of Maguindanao, from the coastal area of Sarangani Bay to the Gulf of Davao.

In the middle of $16^{\text {th }}$ century, when the Spanish expedition had anchored in Manila Bay, Islam was also spreading elsewhere in the Philippines, including the biggest islands of Luzon and Visayas. The area of Manila, now the capital of the Philippines, was in the hands of three Muslim rajahs, namely Sulaiman, Matanda and Lakandula. Though the latter two rajahs submitted to Spanish conquest, Rajah Sulaiman continued to resist until his death in $1588 .{ }^{13}$ During the Spaniards' invasion of Manila, Rajah Solaiman was quoted in his memorable speech saying that "he (Solaiman) was pleased to be the friend of the Spaniards; but that they should understand that he would not tolerate any abuse...; on the contrary, they would repay with death the least thing that touched their honour."14

\section{Spanish Era}

The earliest coming of the Spaniards in the Islands was in 1521 when the Portuguese-born explorer Ferdinand Magellan led a Spanish expedition to the small islet in Leyte, ${ }^{15}$ called Limasawa, where they first celebrated Catholic Mass in the Islands. ${ }^{16}$ Soon after settling on the islet, the conquest and conversion of the local inhabitants began. However, Rajah Lapulapu on the island of Mactan ${ }^{17}$ resisted the conquest and conversion that led to the death of Magellan in the famous Battle of Mactan on 27 April 27 1521. ${ }^{18}$ 
In November 1564, King Philip II of Spain ordered another expedition to go back to the Islands and finally make them permanent colonies. Under Miguel Lopez de Legazpi, with the company of the scholar priest Fray Andres de Urdaneta, the expedition finally landed in Panay ${ }^{19}$ on 27April $1565 .{ }^{20}$ The final colonisation of the Islands began from there with a series of attacks on the Muslim Sultanates. ${ }^{21}$ The motives behind Spain's colonisation, as evident in its official policy, were to spread Faith (Christianity), acquire more territory and to monopolise trade in the so-called Spice Islands. ${ }^{22}$ Spain at that time was one of the world's leading maritime powers and sought to discover more territories, acquire colonies, consolidate power, and open up trade across the Pacific Ocean.

Since Muslim sultanates were already established in the Islands and they were already active in trade, clashes between the two became inevitable. Historians have popularised the "Moro Wars" to refer to a three-century-war between the Spaniards and the Moros. In fact the former had spent almost all its time in the Philippines fighting the latter. ${ }^{23}$ Such a long war had no doubt engulfed hundreds of thousands of lives, burned countless houses, destroyed numerous farms and agricultural livelihoods, and squandered billions of pesos. Perennial antagonism between the Moros and the Christianised-Filipino people has been the pinnacle effect of this devastating war.

In fact, the name "Moro" was coined because of these series of wars. It was initially used by the Spaniards to refer to any individual or group of people who happened to have the same religious practices as the Moors, the Arabs who once occupied Spain for several centuries. ${ }^{24}$ This term was adopted by the Filipinos but only with negative connotations like savage, ignorant, stubborn, or piratical. For the Muslims, however, the name was a source of pride, distinguishing themselves religiously and culturally from the people who succumbed to Christianisation and colonisation. Therefore, the name "Moro" was a "tag chosen for him by his enemy, not by himself", and came to underscore an idea of resistance and anticolonialism. ${ }^{25}$ Since that time, Muslims in the Philippines have been known as "Moros".

The first recorded battle between the Spaniards and the Moros was between Magellan and Rajah Lapulapu on 27 April 1521. When the Spaniards returned under the tutelage of Legazpi, the two forces fought again on 3 June 1571. Rajah Solaiman, the last Muslim ruler of Manila, led his people against the Spaniards in the famous battle of Bangkusay. ${ }^{26}$

The Spaniards' objectives to consolidate territories and convert the Moros to Christianity were clearly spelled out in its official policies towards the Moros. Peter Gowing, an American historian, quotes the instructions of GovernorGeneral Francisco de Sande to Captain Esteban Rodriguez de Figueroa on the siege of Sulu in 1578 and Mindanao in 1596: 
Get them to acknowledge Spanish sovereignty over their territory.

Promote trade with them while obliging them to limit their trade to the Philippine Islands; and discover the natural resources of Moroland with a view to their commercial exploitation.

Begin the Hispanisation and Christianisation of the Moros, in line with the pattern followed in respect to other Filipino groups. ${ }^{27}$

One may notice the anti-Muslim sentiments of the Spaniards towards the Moros. This rancour was grounded in history from the time Muslims ruled Spain for about 800 years. Called by Muslims Andalusia, Spain was once considered one of the Muslim centres of civilisation with the Umayyad Dynasty in Cordova reaching its crowning glory in the $10^{\text {th }}$ century. For the Spaniards in the Philippines, the teachings of Islam were a false and evil law, and the religion of the Christians alone was true, holy, and good. ${ }^{28}$ Majul candidly argued that the Spaniards were angry towards the Borneans because they were "agents for the strengthening of Islam in the Philippines - a faith they had sworn to extirpate". ${ }^{29}$

Although the Spanish offensive war resulted in the destruction of the political and economic infrastructure of the Moros, and the loss of some principalities in Luzon and Visayas, the Moros in general succeeded in thwarting the colonial attempt to permanently subjugate and convert them. ${ }^{30}$ Until its departure in the late $19^{\text {th }}$ century, Spain never successfully held Mindanao in its grip.

\section{American Era}

The United States' colonial presence in the Islands began in 1898 when Spain ceded the Philippines to the Americans through the Treaty of Paris. The Treaty was the outcome of the Spanish-American War that lasted for less than a year. Regent Queen Maria Cristina of Spain declared war against America on 23April $1898,{ }^{31}$ and US President William McKinley reciprocated it on 25 April 1898. ${ }^{32}$ Though the Treaty was signed on 10 December $1898,,^{33}$ it was only ratified and came into effect on 6 February $1899 .{ }^{34}$

When Spain was about to lose the war, it negotiated terms with the American government regarding the future of its colonies. Among the terms, Philippines was ceded to the United States. Article III of the Treaty clearly stipulates that "Spain cedes to the United States the archipelago known as the Philippines Islands..." and Article V, Paragraph 2, states that "Spain will proceed to evacuate the Philippines upon the ratification of the Treaty". ${ }^{35}$ It also stipulated that the "United States will pay to Spain the sum of twenty million dollars" within three months after the ratification of the Treaty. That is, only $\$ 2$ for every Filipino. ${ }^{36}$

America came to the Philippines with a declared mission of spreading democracy and civilisation. Lewis Gould, the American professor who wrote 
a commentary on McKinley's "benevolent assimilation", noticed the racial and ethnic overtones of the phrase. According to him, during the late nineteenth century, "Americans were convinced that their form of government was the best in the world. Asian, Latin American and African peoples were, in the popular mind of the day, not as advanced as were the Anglo-Saxon civilisations. It was the duty [of the Americans] to spread the blessings of civilisation to areas where backwardness persisted." Therefore, McKinley, he continued, "believed that he had a mission to provide the blessings of good and stable government to the people of the Philippines." ${ }^{37}$

However, as far as the Moros in Mindanao were concerned, the realisation of those "benevolent" policies did not reflect the reality on the ground. Instead, chaos and bloodshed ensued over Mindanao. Both the American government and the Moros were claiming the right to sovereignty over Mindanao. The Moros insisted that Mindanao should never have been included in the Treaty as it had never been incorporated and annexed to the Philippine Islands. American sovereignty should be confined to the Northern part of the archipelago, namely the Luzon and Visayas, and the sovereignty over Mindanao should remain in the hands of the Moro leaders. Salah Jubair, the author of the celebrated book Bangsamoro: A Nation Under Endless Tyranny, wryly asked, "How on earth could a nation [Spain] sell a territory she never owned or conquered?" 38

As a sign of protest and resistance, the Moros prepared and built cottas (citadels) all over Mindanao to repel any American incursion into their areas. Subsequently, on 2 May 1902, the first battle between the Moros and the American forces took place in the area of Bayang. ${ }^{39}$ The US forces were composed of the $27^{\text {th }}$ Infantry and $25^{\text {th }}$ Mountain Battery with advanced weaponry. The Moros, on the other hand, numbered around $600,{ }^{40}$ with only swords, arrows, axes, and a very few outdated rifles, ensconced behind bamboo-made forts. Only a day after, the forts were overrun with the death of around four hundred Moro fighters, including the Sultan of Bayang and the Sultan of Pandapatan. On the American side, only 10 soldiers died and 44 were wounded. ${ }^{41}$

The inclusion of Mindanao in the soon-to-be independent Philippines was among the most prejudicial decisions that America had made. It should not be forgotten that the Filipino people in Luzon and Visayas were also revolting against the US Government for complete independence. To assuage the revolution, the American government enacted the Tydings-McDuffie Law, or Philippine Independence Act, ${ }^{42}$ to create the Commonwealth of the Philippines. This Act, authored by Senator Milliard Tydings and Representative John McDuffie, and signed into law by Franklin D. Roosevelt on 24 March 1934, provided for the complete independence of the Philippine Islands after a ten-year transitional period. 
After the lapse of the transitional period, the Manila Treaty was signed on 4 July 1946. This provided the formal recognition of the independence of the Republic of the Philippines and the relinquishment of American sovereignty over the Philippine Islands. Article I clearly stipulates:

The United States of America agrees to withdraw, and surrender, and does withdraw and surrender, all right of possession, supervision, jurisdiction, control or sovereignty existing and exercised by the United States of America in and over the territory and the people of the Philippine Islands... The United States of America further agrees to recognise, and does hereby recognise, the independence of the Republic of the Philippines as a separate self-governing nation and to acknowledge, and does acknowledge, the authority and control over the same of the Government instituted by the people thereof, under the constitution of the Republic of the Philippines. ${ }^{43}$

In addition to that, Article VII of the same Act states:

The Republic of the Philippines agrees to assume all continuing obligations assumed by the United States of America under the Treaty of Peace between the United States of America and Spain concluded at Paris on the 10th day of December 1898, by which the Philippine Islands were ceded to the United States of America... ${ }^{44}$

Finally, the newly independent Republic of the Philippines was born, but the grievances of the Moros were also renewed. As shown in Article VII, the Republic of the Philippines would assume all obligations assumed by the United States of America under the Treaty of Peace, including the exercise of sovereignty over Mindanao. This was a matter of contention for the Moros, for they could not understand how they could be repeatedly included in a ceding agreement, first during the Treaty between Spain and America, and second, with the Treaty between America and the Filipino people, when in fact they should never have been included at all. Besides, the Moros were not even consulted over the inclusion of Mindanao in the Treaty. This again infuriated the Moros.

\section{Post-Philippine Independence Era}

The Spanish and American determination to subjugate Mindanao not only destroyed the infrastructure and the political and social institutions of the Moros, but it also planted the seeds of antagonism and enmity between the Filipinos and the Moros, with both sides ending up holding grudges and animosity towards each other.

Despite the long-drawn war waged by the invaders, the Moros were never entirely subdued. Colonial governments changed strategies, from direct military 
suppression to changing the demography of Mindanao through mass population settlement. According to Abdulwahab Amerol, a senior Moro researcher, the American government thought of changing the demography of Mindanao in order to uproot the Moros from their ancestral and economic bases. ${ }^{45}$ The government promised the Northern Christians to resettle and give them spacious and cultivable lands in Mindanao, giving rise to the slogan "Mindanao: a Land of Promise". The government enacted laws, such as the Land Acts and Commonwealth Act No. 441 , to facilitate the settlement programs.

\section{Land Acts}

Land Acts were initially formulated during the American occupation of the Philippines. After Philippine independence, the new government decided to retain some of the Acts. For the Moros, the Land Acts were a threat to their own survival.

The Land Registration Act No. 496 of $1902^{46}$ was the beginning of the series of Land Acts that provided a legal basis for the US government to dispose the lands all over Mindanao. This particular Act requires the registration and acquisition of land titles in the Philippines. Unregistered lands would then automatically become public domain and open for exploration, occupation and purchase by citizens of the Philippines and the United States. A homestead system was introduced to provide 24 hectares to any individual citizen of the Philippines and 100 hectares for corporations. Additionally, the Public Land Act of 1919 was enacted to supplement the Land Registration Act. It clearly stipulates that all "lands of the public domain ... have reverted or become the property of the Philippine Government..." 47

For the Moros, these Acts were systematic and legalised land grabbing, negating and abolishing the traditional Moro ways for generations of distributing and inheriting land. As Che Man comments, "All Moro ancestral landholdings, which had been passed down from generation to generation as pusaka (inherited property), were no longer valid. Instead, the government reserved to itself the power to issue titles to public land, a possession of which became proof of ownership." ${ }^{\prime 8}$ As a result, most of the Moros did not retain any proof of entitlement to their own ancestral land, and so appeared to have no land and to live on their own ancestral land as if squatters. In Che Man's account, prior to 1912, the Moros owned most of the land in Mindanao, but it was reduced to 30 percent in $1972^{49}$ and further reduced to 17 percent in 1982.

\section{Settlement Projects}

In addition to the laws enacted by the Americans, the Philippine government also legislated various Acts related to settlement projects. These are Commonwealth 
Act No. 441 in 1939, the Act to Further Implement the Free Distribution of Agricultural Lands of the Public Domain in 1954, the Republic Act No. 1888 in 1957, and the creation of the Department of Agrarian Reform (DAR) in 1971.

Commonwealth Act No. 441 created the National Land Settlement Administration (NLSA) in 1939. It was given enormous power and authority by the government to facilitate and accelerate the resettlement of Christians from Luzon and Visayas to Mindanao. Section 2 of the Act stipulates that the Administration shall serve as an agency of the government to "facilitate the acquisition, settlement and cultivation of lands", and "to encourage migration to sparsely populated regions". ${ }^{50}$

This Administration was authorised to hold public agricultural lands for a renewable period of twenty-five years, and to establish credit agencies extending loans to settlers. Additionally, it was to establish and operate electricity and water supply plants, irrigation systems, trading stores or cooperatives and to essentially improve and promote the well being of the settlers. It could also act as an agent, broker, commission merchant, or representative of the settlers in marketing products raised or produced by settlers, and could borrow, issue bonds, or raise funds whenever deemed necessary in the interest of the settlers. The Administration was allocated a sum of twenty million pesos for direct and immediate expenses of the project. ${ }^{51}$

During the time of President Manuel L. Quezon in 1944, the policy of settlements in Mindanao had become national policy. President Quezon's speech during the first session of National Assembly partly reads:

The time has come when we should systematically proceed with and bring about colonisation and economic development of Mindanao. A vast territory with its untapped natural resources is a temptation to interfering nations that are looking for an outlet for their excess population.... If we resolved to conserve Mindanao for ourselves and our posterity, we must bend all efforts to occupy and develop it. ${ }^{52}$

Government settlement programs intensified thereafter. In 1954, an Act to Further Implement the Free Distribution of Agricultural Lands of the Public Domain ${ }^{53}$ paved the way for the establishment of the National Resettlement and Rehabilitation Administration (NARRA). This Act was to "help speed up the free distribution of agricultural lands of the public domain to landless tenants and farm workers who are citizens of the Philippines and to encourage migration to sparsely populated regions..." NARRA was then given substantive power to carry out the settlement program:

To give land ... to landless citizens of the Philippines who need, deserve and are capable of tilling the land; to facilitate the settlement, acquisition and cultivation of 
agricultural lands; to borrow money from any credit institution for any of the purposes herein provided; and to secure for the settlers from other government agencies such assistance and facilities as may be necessary to accelerate development, cultivation and electrification of settlements; construction of irrigation systems; institution of credit facilities, enhancement of cottage industries; and establishment of processing plants, warehouses and marketing facilities. ${ }^{54}$

In addition, NARRA would "assist settlers in transporting themselves, their belongings, work animals and farm equipment, if any, from the communities from which they were migrating to the settlement areas reserved for the purpose, and for subsistence necessary until credit can be provided . . . and these loans shall be non-interest bearing..." Furthermore, NARRA was also "to assist the said settlers in securing equipment, supplies and materials needed in the settlement areas at the most advantageous prices or terms...", and to "help provide housing and other accommodations for the new settlers in the settlement areas upon arrival by locating them in properly surveyed and subdivided lots... to help organise community activities that the new settlers require upon arrival in the new settlement ..." 55

The 1954-1955 fiscal year allocated five million pesos to this Act, and a sum of not less than eight million pesos for every fiscal year thereafter, for a period of ten years. The Agricultural Credit and Cooperative Financing Administration (ACCFA) was also to "give loans or financial assistance to the settlers or cooperative settlers to help establish themselves as independent farmers following their arrival in the settlement areas." 56

In 1971, President Ferdinand Marcos signed into law the Republic Act No. 6389 to create the Department of Agrarian Reform (DAR) and to "provide a more vigorous and systematic land resettlement program and public land distribution." ${ }^{57}$ DAR would establish "an institution" to finance the acquisition and distribution of agricultural land and "Bureau of Resettlement" that would be responsible for "resettlement of displaced farmers, landless families, and urban workers in the settlement projects of the Department, the construction of houses, roads and other facilities ..." 58

The DAR was given a Cabinet post in order for the president to maintain close supervision, and the Land Bank of the Philippines, one of the leading banks in the country, was designated as the financing arm of the department.

All of the above measures and policies facilitated resettlement in Mindanao. For Christians all over the country, it was a "dream come true". A vast stretch of land in Mindanao was opened to large-scale migration from the northern and central parts of the Philippines which would forever change the demography of the region. In 1912, the first known settlers in Mindanao were Christian Cebuanos 
from Visayas, numbering around a hundred families..$^{59}$ In 1913, the American colonial government began implementing a policy of establishing agricultural colonies in the south to encourage farmers from both Luzon and the Visayas to resettle in Mindanao. From that year until 1917, seven agricultural colonies were opened in Mindanao. These were in Pikit, Silik, Paidu Pulangi, Pagalungam, Glan and Talitay in the former empire province of Cotabato, and Momungan in Lanao province. ${ }^{60}$

From the year 1918-1939, there were 9,172 families, equivalent to 46,712 individuals, from Luzon and Visayas that had resettled in Mindanao. ${ }^{61}$ In 1939 alone, there were 200 Christian families who had been given twelve hectares of farmland and financial aid of up to P7.5 million each, assistance that made the settlers, according to Jubair, cry and kiss the ground in excitement. ${ }^{62}$ By 1960 , as many as 3,200 migrants were arriving in Mindanao every week. ${ }^{63}$ In just a period of ten years, from 1960 to 1970, an estimated total of 362,000 people had migrated to Mindanao. ${ }^{64}$ In 1975 and early 1976, 49 settlement projects served 47,900 families, resettling roughly 1 per cent of the rural population of the Philippines ${ }^{65}$ in Mindanao under the administration of DAR. In 1977, the Ministry of Agrarian Reform (MAR), the successor of DAR, was administering a total of 44 settlement programs, with an aggregate area of 734,825 hectares and 49,898 families. ${ }^{66}$

Table 1 shows that from 1950 to 1978, within just a span of 28 years, more than 700,000 hectares of Moro land were given to almost 50,000 Christian families. As a result, there are now three main clusters of population in Mindanao: the Moros, the Lumads (the native people of Mindanao who neither embraced Islam nor Christianity) and the Christian settlers.

\section{Jabidah Massacre}

The Jabidah Massacre took place on 17 March 17 1968. Occasionally called the Corregidor Massacre, it involved the killing of 64 young Muslim trainees ${ }^{67}$ in the Philippine Army by their Christian superiors. It was the first major carnage directed towards the Moros after the independence of the Philippines. Muslims all over the country deplored the massacre, and Muslim students in Manila held a weeklong vigil in front of the Malacañang Palace, the president's office, demanding justice for the victims.

Vitug and Gloria, the authors of the widely-quoted book Under the Crescent Moon: Rebellion in Mindanao, explained that "Jabidah" was the name of the commando group involving hundreds of recruits under the pseudo code "Project Merdeka" ${ }^{68}$ The hidden mission of this project was initially to destabilise Sabah ${ }^{69}$ and gradually take over the resource-rich island by invasion. According to the 
lone survivor of the massacre, Jibin Arola, the Muslim trainees wanted to back out upon knowing that the real mission was to invade Sabah, not to fight the Communist insurgents as was said during recruitment. ${ }^{70}$

Table 1 Christian Settlements in Mindanao from the year 1950 to 1978

\begin{tabular}{|c|c|c|c|c|c|}
\hline No. & Year & Settlement Project & $\begin{array}{l}\text { Location } \\
\text { (all in Mindanao) }\end{array}$ & $\begin{array}{l}\text { Area } \\
\text { (ha) }\end{array}$ & $\begin{array}{c}\text { No. of } \\
\text { Settler } \\
\text { Families }\end{array}$ \\
\hline 1. & 1950 & Bukidnon & $\begin{array}{l}\text { Maramag-Pangantukan- } \\
\text { Kalilanoan }\end{array}$ & 35,399 & 4,336 \\
\hline 2. & 1950 & Lanao del Sur No.1 & Wao & 18,000 & 4,002 \\
\hline 3. & 1953 & $\begin{array}{l}\text { Lanao del Norte No. } 2 \\
\text { (Arevalo Edcor) }\end{array}$ & Sapad & 3,000 & 139 \\
\hline 4. & 1953 & $\begin{array}{l}\text { North Cotabato No. } 2 \\
\text { (Genio Edcor) }\end{array}$ & Alamada & 28,380 & 899 \\
\hline 5. & 1953 & $\begin{array}{l}\text { Maguindanao No. } 2 \\
\text { (Callego Edcor) }\end{array}$ & Buldon & 5,464 & 241 \\
\hline 6. & 1955 & Tawi-Tawi & Balimbang-Bongao & 15,340 & 723 \\
\hline 7. & 1955 & Davao del Norte No. 1 & Sto. Tomas: Tibal-og - La Libertad & 7,225 & 970 \\
\hline 8. & 1956 & North Cotabato No. 1 & Carmen & 100,000 & 2,019 \\
\hline 9. & 1956 & Sultan Kudarat No. 1 & Columbio-Tulunan & 52,468 & 2,378 \\
\hline 10. & 1960 & Lanao del Norte No. 1 & Tangkal-Magsaysay & 13,943 & 1,019 \\
\hline 11. & 1962 & Zamboanga del Norte & Liloy-Salug-Sindangan & 35,000 & 2,343 \\
\hline 12. & 1962 & Agusan del Sur & Talcogon-Esperanza-Sindangan & 35,000 & 2,343 \\
\hline 13. & 1967 & $\begin{array}{l}\text { Maguindanao No. } 1 \\
\text { (Barrira Edcor) }\end{array}$ & Barrira & 33,000 & 375 \\
\hline 14. & 1968 & Sultan Kudarat No. 2 & Isulan-Bagumbayan & 30,000 & 1,497 \\
\hline 15. & 1970 & Davao del Norte No. 2 & Asuncion & 8,221 & 2,926 \\
\hline 16. & 1973 & Lanao del Sur No. 2 & Lumba-a Bayabao-Bubong & 6,939 & 246 \\
\hline 17. & 1975 & Maguindanao No. 3 & Upi-Dinaig & 4,268 & 130 \\
\hline 18. & 1975 & Lanao del Norte No. 3 & Nunungan-Karomatan & 19,674 & 337 \\
\hline 19. & 1975 & Lanao del Sur No. 3 & $\begin{array}{l}\text { Bayang-Binidayan-Pagayawan- } \\
\text { Tuburan (Tatarican) }\end{array}$ & 18,197 & 770 \\
\hline 20. & 1976 & Sulu & Panamao-Talipao-Patikol & 7,146 & 219 \\
\hline 21. & 1976 & Basilan & Lamitan-Sumisip-Maluso & 15,000 & 460 \\
\hline 22. & 1978 & Lanao del Sur No. 4 & Kapai & 5,500 & - \\
\hline 23. & 1978 & South Cotabato & Sorollah & 22,000 & - \\
\hline & & & TOTAL & 737,656 & 49,796 \\
\hline
\end{tabular}

Source: Ministry of Agriculture, quoted in Uhlig, 27. 
As testified by Arola, the trainees asked, how could they [we] attack the Malaysians when they are our brothers and we do not have any quarrel with them $?^{71}$ Since the nature of the project was a top military and political secret, the military officers decided to kill all the trainees in order to prevent it from being disclosed to the public. The Army Chief subsequently was ordered to clean up the evidence by collecting all the charred flesh and bones, together with the bullet shells lying on the airstrip, and dumping them into the sea with heavy stones tied to them to make sure that nothing would float to the surface. ${ }^{72}$

The massacre served as the turning point for the Moros in the Philippines. As Vitug and Gloria put it, "Muslim Mindanao was never the same again." ${ }^{.73}$ It served as a catalyst for the Moros to take up arms and fight against the oppressive neo-colonial government. Muslims in the international community, especially Malaysia and Libya, also voiced anger over the massacre:

This incident caused much furore in the country, with the members of the then political opposition using it in lambasting the Marcos administration. The Philippine press also denounced this horrible incident which caught the administration flatfooted. Internationally, the incident caused the Philippine government to earn the ire of several Muslim countries. Most outraged among them was Malaysia, who saw the incident as an indication of the strong determination of the Philippine government to annex the state of Sabah, over which Marcos' predecessor expresident Diosdado Macapagal filed a claim in 1962. ${ }^{74}$

Two major implications of this incident are worth noting. First, since the apparent mission of the aborted Project Merdeka was to destabilise and ultimately invade Sabah, its Chief Minister Tun Mustapha retaliated by publicly declaring his support for the Moros. Tun Mustapha promised to give arms and military training, provide monetary and logistic support, and most importantly offer them sanctuary and safe haven. ${ }^{75}$ Second, since the government failed to give justice to the victims (all the 24 court-martialed officers and men were acquitted and no single person was held accountable) ${ }^{76}$ the Moros felt betrayed by the government. The idea of having an independent state was once again rekindled.

\section{ILAGA-related massacre}

The word Ilaga is a literal Visayan ${ }^{77}$ term for rat, a creature that greedily infests crops. Some Moros believe that the name was adopted to imply the determination of the Christian settlers - the perceived founder of the group - to devour further the livelihood, land and farms of the Moros. However, some accounts believe that the word is the acronym for the Ilonggo Land Grabbers' Association, entailing the all-capital letters of ILAGA. In any case, the group was known for savagery and cruelty, possibly making it more notorious than the Jabidah Massacre. The 
group carried out numerous atrocities, such as massacres of civilians, ransacking villages, looting properties, and burning houses and mosques. Even worst, the group did not simply kill the Moros, but also mutilated the bodies, carving out ears, slashing nipples, plucking out eyes, and marking bodies with the cross. ${ }^{78}$

The Manili Massacre on 19 June 1971 was one of the most horrible massacres carried out by the group. Seventy Moros, including women and children, were mercilessly massacred in Barrio Manili, Carmen, North Cotabato. Teng Addie Nagli, one of the surviving victims of the massacre, and a seven-year old child at the time, has only the faintest memories of that fateful day. He recalls:

The community was called for a meeting inside the mosque at dawn by Philippine Constabulary (PC) Captain Langgan. He said men, women and children braved the rain and biting cold to be able to attend the meeting. We had no idea that the supposed-to-be peace and order meeting would snuff the lives of many of our relatives and neighbours. When all the people were inside the mosque, the armed men bolted the men's entrance but kicked open the women's entrance. Then the armed men ordered (my) father to go out and surrender his guns and other firearms, (but) we had no firearms so there was nothing to surrender. They brought my father to our house a few meters away from the mosque and then I heard shots. They killed my father at close range. Captain Langgan then told the people inside the mosque to call on their God and pray because they would all be killed. So they lobbed a grenade at the mosque and I felt myself lifted from the ground. Then I saw body parts stick to the ceiling of the mosque. ${ }^{79}$

Nagli recalls that he was shielded by others nearer to the grenade. "All I can remember (was) the blood was so warm and bodies heaped all over me so the soldiers did not see me still alive." He said that he could not forget the stench of the ankle-deep blood, which flooded the floor of the mosque. "I'll never forget what I saw till the day I die. Even up to now when I think about it, my heart tightens. It makes me want to take revenge because the wounds of the incident are still here." $" 80$

The Manili Massacre was not an isolated incident. Jovi, ${ }^{81}$ one of the survivors of the similarly horrific Pagayawan Massacre, recalled the long and painful story of how they were ruthlessly struck by the ILAGA. According to him, it was two o'clock in the afternoon on Tuesday, 22 September 1972 when most of his relatives were killed and he himself almost died. He narrated that "most of the victims were not yet in their 20s. I was just around 13-year-old boy. The oldest among the casualties was 15 years old, while the youngest was just around 2 to 5 months, for those babies were just in their cradle when the ILAGA and uniformed soldiers struck." He continued, "While the uniformed soldiers took the task of gunning us down, the ILAGA did the mutilation. Those babies inside the room 
were brought out and thrown over to the ILAGA for mutilation and beheading." "Then when they thought that we were all dead," he concluded, "they began looting the house before they finally left. All in all, out of 28, eleven died while others were maimed after sustaining multiple stabs." When asked why most of them were young and why they were so crowded in just one small house, he emotionally recalled that most his uncles and cousins were already massacred in the adjacent area of Dilabayan, Kauswagan. All in all, more than 200 of his relatives were massacred by the ILAGA.

The Manili and Pagayawan Massacres were just two of the numerous massacres that occurred from 1970 to 1972 . Other massacres carried out by the ILAGA are summarised in the following table.

\section{Table 2 List of massacres committed by ILAGAS in Mindanao}

\begin{tabular}{|l|l|c|c|c|}
\hline Municipality/Province & \multicolumn{1}{|c|}{ Year } & Dead & Wounded & $\begin{array}{c}\text { Burned- } \\
\text { houses }\end{array}$ \\
\hline 1. Upi, Cotabato & March 22, 1970 & 6 & 2 & Ud \\
\hline 2. Upi, Cotabato & September 10,1970 & 6 & Uk & Uk \\
\hline 3. Polomolok, South Cotabato & August 10, 1970 & 8 & Uk & Uk \\
\hline 4. Alamada, Cotabato & December 3, 1970 & 13 & Uk & Uk \\
\hline 5. Midsayap, Cotabato & December 16, 1970 & 18 & Uk & Uk \\
\hline 6. AHan, Datu Piang, Cotabato & December 21,1970 & 7 & Uk & 147 \\
\hline 7. Bagumbayan, Cotabato & January 1,1971 & 12 & Uk & Uk \\
\hline 8. Alamada, Cotabato & January 17, 1971 & 73 & Uk & 36 \\
\hline 9. Carmen, Cotabato & April 6, 1971 & 18 & 25 & Uk \\
\hline 10. Manili, Carmen, Cotabato & June 19, 1971 & 70 & 17 & Uk \\
\hline 11. Wao, Lanao Sur & July 4, 1971 & Ud & Uk & 60 \\
\hline 12. Buldon, Cotabato & August 5, 1971 & 14 & Uk & Uk \\
\hline 13. Wao, Lanao Sur & August 5, 1971 & 36 & Uk & Uk \\
\hline 14. Kauran, Ampatuan Cotabato & August 9, 1971 & 4 & Uk & Uk \\
\hline 15. Buldon, Cotabato & August 9, 1971 & 60 & Uk & Uk \\
\hline 16. Kisulon, Bukidnon & October 23, 1971 & 67 & Uk & Uk \\
\hline 17. Magsaysay, Lanao del Norte & October 24, 1971 & 66 & Uk & Uk \\
\hline 18. Tacub, Kauswagan, & November 22, 1971 & 40 & 140 & Uk \\
\hline Lanao del Norte & November, 1971 & Uk & Uk & Uk \\
\hline 20. Ipil, Zamboanga del Sur & December, 1971 & Ud & Uk & Uk \\
\hline 21. Palembang, Cotabato & January 21, 1972 & Ud & Uk & Uk \\
\hline & & & & \\
\hline
\end{tabular}

Note: $\mathrm{Uk}=$ Unknown; Ud=Undetermined 
Table 2 shows the intensity of the violence in almost every province of Mindanao. In less than two years, 21 massacres took place with more than 500 fatalities and 184 injuries. According to the government's estimate, more than 1,000 civilians and about 2,000 armed Moros and Christians were killed, and more than half a million persons were displaced or rendered homeless. ${ }^{83}$ Another source puts the total number of casualties as high as 10,000 lives. $^{84}$

In perpetrating all these atrocities, the ILAGA was enjoying direct assistance from the government. They were provided with necessary information and sophisticated weapons. In some incidents, military personnel were themselves the prime culprits. In the case of the Manili Massacre, it was none other than Captain Langgan who cordoned the local residents into a mosque and ordered their killings. Another ILAGA leader, Feliciano Lucas, was reported to have given a red carpet reception at the Malacañang Palace in Manila when he "surrendered" to President Marcos ${ }^{85} \mathrm{He}$ was afterwards released to his hometown with military escort to protect him from being killed or arrested because of the warrants issued against him. Instead of being punished, the ILAGA leader was, according to the late Congressman Salipada Pendatun, knighted and "bade to go back to his kingdom to bear more arms and commit further depredations." ${ }^{96}$

In the wake of all these incidents, the Muslim leaders - senator, former senator, congressmen, government officials, heads of Muslim associations, religious and academic scholars and intellectuals, professionals and businessmen, as well as student leaders - met in a private house and pledged before the Qur'ān to set aside all political, personal and ethnic differences and to commit themselves to protect the Moros.$^{87}$ Various factions and liberation groups were born, but Moro leaders and politicians were united in calling for independence. Among these was Ustaz Salamat Hashim who founded the Moro Islamic Liberation Front (MILF).

\section{Islamic Revivalism: The Approach of the MILF}

The MILF started as a breakaway group from the Moro National Liberation Front (MNLF). During the early period of the struggle, Salamat Hashim was the MNLF vice-chairman and the head of foreign affairs. The two leaders were working together very closely. Hashim even helped Misuari to get the post of chairmanship. ${ }^{88}$ However, because of differences of ideology and leadership style, ${ }^{89}$ the two leaders began to disagree on most issues. Hashim began challenging Misuari in cases he considered un-Islamic, while Misuari started to decide matters and convening major sessions without consulting Hashim. Nonetheless, all this wrangling had been confined only to the high-ranking members of the group.

On 21 September 1977, right after the collapse of the negotiations in Manila, the divisiveness became known to the public. The fifty-seven leading officers 
of the Kutawato Revolutionary Committee (KRC), the biggest single unit in the entire MNLF in terms of numbers and territorial jurisdiction, signed a petition addressed to the OIC and the Muslim World League (MWL) calling for the ousting of Nur Misuari as Chairman and instead recognising Salamat Hashim as the new Chair. ${ }^{90}$ Many more petitions from Cotabato, Lanao, Zamboanga del Sur, and Davao were forwarded to the OIC and MWL.

Subsequently, Hashim announced his "Instrument of Takeover" on $24^{\text {th }}$ December 1977 to finally declare his chairmanship. ${ }^{91}$ Hashim justified his takeover by the following:

The MNLF leadership was being manipulated away from its Islamic basis, methodologies and objectives, and fast evolving towards a Marxist-Maoist orientation.

... The Central Committee has evolved into a mysterious, exclusive, secretive, and monolithic body whose policies, plans and decisions - political, financial, and/or strategic - became an exclusive preserve of Nur Misuari.

This mysterious, exclusive and arrogant nature of the MNLF leadership resulted in confusion, suspicion and disappointments among members and mujahideen in the field, resulting in the loss to the cause of a great number of freedom fighters. ${ }^{92}$

However, Misuari refused to recognise the takeover and the allegations. $\mathrm{He}$ instead accused Hashim of treachery, incompetence and insubordination, stripped him of his MNLF posts and declared him persona non grata..$^{33}$ The OIC and the MWL mediated between the two leaders in an attempt to settle the internal strife, but it was to no avail. Finally, the two leaders took their separate ways.

In March 1984, the MILF officially established itself as a separate organisation, emphasising Islam as a guiding principle in all its affairs and activities. Hashim declared in his widely-disseminated book, The Bangsamoro Mujahid: His Objectives and Responsibilities, that the "ultimate aim of our Jihad is to make the Word of Allah supreme." "94 Muslims must subordinate every aspect of their worldly wishes and desires to the Word of Allah, including their political, economic, educational, and social systems. Making the Word of Allah Supreme entails the establishment of a true Muslim community, the establishment of a genuine Islamic system of government and the application of a real Islamic way of life. ${ }^{95}$

Hashim was among the students who were granted scholarships by Egyptian government to study at al-Azhar University. Having spent ten years in Egypt, Hashim had become heavily influenced by Muslim revivalists, most notably Hassan al Banna and Syed Qutb. In fact, the latter's Milestone shaped Hashim's Islamic outlook and political beliefs. ${ }^{96}$ Hashim's contemporaries in Al-Azhar 
included Burhanuddin Rabbani and Abdul Rasul Sayyaf, and both became the leaders of Afghanistan's anti-Soviet mujāhideen. ${ }^{97}$ Hashim was thus widely viewed as an Islamist revolutionary leader who wanted to liberate the Moros from the yoke of oppression and establish Islam as a way of life. For his supporters, Hashim was a reformer who can be compared with popular reformers in the Muslim world, such as Omar bin Abdul Aziz, Imam Shafi'e and Ibn Taimiyyah. ${ }^{98}$

Paramount to his vision was the establishment of an Islamic government, which he considered to be required for the perfection of the Muslim's 'ibadāh (devotion) to Allāh. According to him, 'ibadāh is not only limited to the basic tenets of Islam, the five pillars, but also includes political affairs, business transactions, social relations, education, culture, and all other aspects of life. ${ }^{99}$ Everything in society must be according to Islamic teachings.

In realising his vision, Hashim outlined four-point programs with a time frame of 50 years. They are Islamsation of the Bangsamoro people; strengthening and improving the organisational and administrative capability; military build-up; and self-reliance.

\section{Islamisation}

The Islamisation program concerns primarily the Moro population, which tends to separate religion from the state, as is the case in the Western countries. Hashim wanted to reverse this trend and called on the Moros to follow Islam more faithfully and reform their lives, homes and society. As Joseph Chinyong Liow wrote:

Hashim proposed that it was through da'wah and jihad that the MILF Islamisation agenda, which comprised of the transformation of every Muslim in MILF into "a true and real Muslim whose belief... and his entire life is in conformity with the teachings of Islam derived from the Qur'an and Sunnah", of every MILF home into "real Islamic homes where the teachings of the Qur'an and Sunnah prevail", and of community into "a true Islamic one governed by the Shari'ah" would be realised. ${ }^{100}$

Hashim reiterated the need of having God-fearing leaders in order for the community to be Islamised. He wanted to reinstate the practice during the time of the Prophet (pbuh) where the affairs of the government and faith were inseparable. As he declared, "Practicing Islam without governmental sanction is a truncated version of the faith and, therefore, un-Islamic. A government not founded on Islamic principles (Qur'ān and Sunnah) is unquestionably unIslamic." ${ }^{101}$ Hashim urged the Bangsamoro people not to limit their 'ibadāh to the performance of the five pillars of Islam, but to engage in the political, social, cultural, and economic affairs of society. He asserted that active involvement in and support of the Bangsamoro struggle is 'ibadāh or service to Allah (swt). ${ }^{102}$ 
The MILF introduced programs to promote the awareness and practice of Islamic teachings, initially among MILF members who should serve as role models for the general public. Two large MILF camps, Camp Abubakar and Camp Bushra, have always been locally referred to as "Dārussalām" (abode of peace) and "Dārul Imān" (abode of faith), reflecting their adherence to the Islamic way of life.

Before Camp Abubakar was captured by the government forces in 2000, observers would feel a marked difference from the outside community because of the prevalence of Islamic practices and injunctions. Aside from being the general headquarters of the MILF, Camp Abubakar also resembled a full community that has religious, economic and military structures. Also, schools, madrasah, mosques, Sharī'ah courts, and multi-purpose cooperatives were also constructed inside the camp.

Similarly in Camp Bushra, the stronghold of the vice-chairman Aleem AbdulAziz Mimbantas, an Islamic ambiance could also be felt. A madrasah ${ }^{103}$ called Ma'had Palestine has been established since the foundation of the camp. Named as such to constantly remind the local residents and the mujähideen ${ }^{104}$ about their obligations and supplications towards their Palestinian brethren, the main purpose is to give Islamic education to the locals, most especially the children and families of the mujähideen. Mimbantas underscored that this madrasah is to "give an opportunity to the people who were deprived of basic education, either Islamic or Western, to at least learn how to read and write". ${ }^{105}$ According to him, they ask their 'ustāz (Arabic teacher) to teach those children. Most of them gave one day a week, but some devotedly gave their full time. As a result, the MILF have produced students who are really committed to the Islamic cause and to the organisation. In certain cases, the MILF has even managed to send a few students to study abroad.

The MILF's Islamisation program also includes the setting up of Shari' 'ah court inside the camps. Moro scholars who had specialised in Islamic jurisprudence, Fiqh and Usül al Fiqh were given the task of handling cases. Sharī'ah lawyers were placed in charge of looking into the details of all cases submitted to the MILF's court.

During the heyday of the MILF in Camp Abubakar, all kinds of criminal cases were submitted to its Sharī'ah court, ranging from killing to stealing. Punishments were given based on the committed crimes and offences, including 100 lashes for fornication between unmarried man and woman, ${ }^{106}$ hard labour for those who steal to pay their debts, imprisonment for recidivists, and execution for murderers. The MILF claims that all such punishments are based upon the injunctions of the Qur'ān and Sunnah. 
The last reported execution in Camp Abubakar was in 1985, ${ }^{107}$ but a more recent one in 1997 took place outside the MILF's camp. According to Mimbantas, "we decided for the execution to take place outside Camp Bushra in order to show the growing influence of the MILF and to let as many people as possible witness the execution." The main purpose of this was to serve as a deterrence for other people not to commit the same crime. In Islam, he added, "the aim is not really the execution, but to achieve peace and order in the community. It may be harsh in the eyes of the common people, but this is merely implementing what Allah has ordered us to do. The Qur'ān and Sunnah are very clear about this, so we should not doubt and compromise even a little."

To this day, Shari'ah court remains operational in some MILF-controlled areas. The MILF leadership recently approved the North Western Mindanao Front Mobile Sharī'ah Court to be under the command of Abdullah Macapaar, the commander in chief of the Front. Alias Commander Bravo, he has been given a mandate to continue operations against all anti-Islamic teachings and to put suspects into prison while waiting for the final verdicts. As Bravo explains, this kind of court is "just a branch of the MILF Shari' ah Court that implements all Islamic injunctions. We search for people who have criminal records, who engage in unlawful sexual intercourse, who are involved in drugs or any kinds of gambling, who drink alcohol, and who do any other deceitful activities." However, Bravo quickly pointed out that "we have to accept the reality that we are not yet completely independent, thus, our operations are only confined to some specific areas."

The mobile Shari' 'ah court is composed of twenty competent and learned people who are in charge of giving verdicts. "In every different case, we have to look back to the Qur'ān and Sunnah," one of those twenty learned people affirmed. When it is not explicitly mentioned in the Qur'ān and Sunnah, the group is given full authority to come up with a verdict based on their own intellect and reason.

Other Islamic injunctions are also observed in the MILF-controlled areas. Inside the two camps, women are not allowed in public if they are not dressed decently. They must have clothes and veils that cover their bodies and heads. Furthermore, male-female contact between non-immediate relatives is strictly prohibited; business transactions are also regulated to make sure that $r i b \bar{a}^{109}$ and other such transactions do not take place; prices in the market are monitored to avoid overpricing; weighing scales and tape measurements are checked to avoid cheating; and most importantly, foods and beverages are screened to avoid non-halāl foods and alcoholic drinks. The locals had always referred to Camp Abubakar as dārussalām and Camp Bushra as Dārul İmān because social justice and peace and order are seen inside the camps. While the series of punishments and executions required the locals to behave according to Islam, the MILF gained 
credit for controlling the areas by providing the people with social justice.

The MILF Islamisation programs also targeted drug trafficking and gambling. ${ }^{110}$ When drug trafficking became rampant, and drug addiction among the Muslims reached an alarming level, the MILF mobilised its own special team to launch operations against drug lords. In the late 1990s, the MILF was reported to have been very active in drug-related operations in Marawi city, Lanao del Sur.

More recently in 2011, the MILF engaged once more in an operation that succeeded in capturing a few serial killers, prominent drug lords, people involved in various kinds of gambling (including cock-fighting), and eradicating venues of gambling and cock-fighting. ${ }^{111}$ Dubbed "Bismillah", the most significant feature of this operation was that it was focused in the area of Masiu, the birthplace of the vice-chairman Mimbantas, in order to demonstrate the seriousness of the MILF leadership intention to curb drugs and gambling-related activities. ${ }^{112}$

The MILF has constructed its own rehabilitation centres in Camp Abubakar and Camp Bushra for the prisoners to undergo rehabilitation and re-orientation programs through the da'wah (Preaching Islam) and educational schemes. Reading the Qur'ān with exegesis, fasting every Monday and Thursday, hourlong midnight prayers, and physical exercises are seen as part of the rehabilitation program.

\section{Strengthening the Organisation}

Unity is one of the basic requirements for any organisation to succeed, and much more for an Islamic call, as it is not an individual task, but a collective duty and obligation. History attests that during the time of the Prophet (saw), priority was given to strengthening the organisation. Emulating the Prophet (saw), Hashim maintained that an organisation must be founded on shüra (consultation), justice and equality, for "justice is the natural consequence of shura and equality is the natural consequence of justice. There will be no equality if there is no justice, and there will be no justice unless the affairs of men are conducted through consultation." 113

Hashim wanted the MILF to be a mass-based organisation that could represent the various ethnic groups in Mindanao. He ensured that MILF's Central Committee, responsible for the day-to-day affairs of the organisation, would be composed of different ethnic groups in Mindanao and sectors from professionals, businessmen, politicians, and youths.

The MILF maintained its mass base support from the areas of Maguindanao, Lanao del Sur, Lanao del Norte, North Cotabato, and Basilan. ${ }^{114}$ On 5-7 October 1986, MILF held a military consultative assembly which more than one million people from all over Mindanao attended, and almost eighty thousand of them were armed with various kinds of weapons. ${ }^{115}$ Additionally, in 2005, MILF 
general consultation had managed to gather more than three million supporters, although the media put it as several hundred thousand. Even then, Joseph Liow was prompted to emphasise that "this was more than the MNLF could ever muster, making the MILF by far the largest and most powerful resistance group operating in southern Philippines today." 116 Lastly, another proof of the MILF's mass appeal can be observed in the following remark:

The Armed Forces of the Philippines [AFP] faces serious difficulty in gathering information from the MILF controlled areas because most of the local population refuses to cooperate with them. The mass support enjoyed by MILF is largely due to its emphasis on Islamic symbols and substance of liberation movement. ${ }^{117}$

Apart from those reasons mentioned above, the MILF ensures its stability by dividing the key executive positions between the two largest ethnic groups in Mindanao: the Maguindanaon and Maranao. While the chairmanship was given to Hashim, a Maguindanaon, one of the deputy positions was given to Abdul Aziz Mimbantas, a Maranao and an al-Azhar graduate who was in charge of implementing Qur'ānic teachings in his own area of control. The unity of the MILF is reflected in the smooth succession of the chairmanship after Hashim's sudden death. ${ }^{118}$ With three deputies, it would not have been uncommon to encounter a bumpy succession. In the event, however, Hashim's successor al-Haj Murad was given the post wholeheartedly and without challenge from the other two deputies. As Mimbantas claims, "This is perhaps the only revolutionary organisation in the world that has had such a smooth succession. Instead of fighting as to who should succeed the chairmanship, the three deputies were all with the idea of putting someone to the post other than himself."

\section{Military Build-Up}

MILF focuses equal attention on its military capacity. According to Hashim, military build-up is the main mechanism to implement the Islamisation programs and to repulse any aggression against Islam. Hashim strictly adhered to the Islamic principle that when a Muslim community is persecuted, oppressed or denied liberty and freedom to perform its duties to Allah, then armed struggle becomes an obligatory duty to each and every Muslim. ${ }^{119}$

During his time, the MILF established its own military academy, the Abdulrahman Bedis Memorial Academy, for the new recruits to undertake physical and spiritual training before joining the ranks. While the physical training requires the trainees to master obstacle courses, march drills and fire several types of weapons, the spiritual training focuses on lectures regarding Islam and jiha $\bar{a} .{ }^{120}$ Benjie Midtimbang, one of the training directors, has stated: 
We are not strict with educational background, only their loyalty to the faith, the cause, and their sincerity. We put more stress on Islamic spiritual training rather than on the physical and mental aspects. Fasting twice a week is optional for the trainees but hour-long midnight prayers are must. ${ }^{121}$

After the demise of Hashim, the new leadership decided to rename and relocate the military academy in his honour. The Salamat Hashim Islamic Memorial Military Academy (SHIMMA) is now located in Camp Bushra, where Hashim died, and is training the military forces of the Front. ${ }^{122}$ SHIMMA has three months of training, and admission criteria are stricter. In accordance with Hashim's vision, spiritual or moral superiority is given more importance than physical or material strength in recruiting new members, because the former does not depend on the availability of the factors that sustain physical existence, such as food, clothing and other material needs. ${ }^{123}$ Spiritual strength draws its energy and force from a source invulnerable to physical destruction. "When an army is defeated militarily," Hashim stressed, "it can still rebuild, reorganise and recoil into an even greater attack. But when an army is defeated morally and spiritually, all the material weapons at its command become useless pieces of hardware and it will be permanently subdued by the victor." 124 For Hashim, military defeat is only temporary while moral defeat is permanent.

\section{Self-Reliance}

The MILF has sought to promote socio-economic development and self-reliance among its members. According to Murad, "this concept is the first and foremost concept that we taught to our members. The ultimate reason for this is to become not solely dependent on the monetary help coming from outside, most especially the Arab World, as was the MNLF case." Members of the organisation are encouraged to engage in some livelihood to sustain themselves and their organisational needs.

MILF's military personnel are not permanently stationed in their various camps so as to give them ample time to maintain their livelihood. These livelihoods range from farming, fishing, and trading to teaching and running small and big businesses in the cities, including Manila. Some manage to get positions as teachers, security guards, policemen, or soldiers.

Financial self-reliance is being achieved to a great extent, most especially with the high-ranking officials of the MILF. The late chairman Hashim was reported to have various investments in the Philippines; the late vice-chairman Mimbantas was a missionary of Libya's Islamic Call Society; the current chairman Murad has various businesses, such as rice mills, restaurants, taxi-lending, and lodgings; and Ghazali Jaafar, the vice-chairman for political affairs, has his own farm 
and logging businesses. For the lower-ranking members, however, the concept is not that successful. Although most are involved in farming, fishing or small businesses, the rest still rely on donations. As Murad acknowledges, "only about $50 \%$ of our members have achieved the status of self-reliant. The rest are either supported by relatives and family members or relying on donations. Therefore, asking donations from abroad is not completely ruled out." According to Jaafar:

We have not received funds from foreign countries with preconditions for military activity. We have been receiving contributions from people of the world, some people in Saudi Arabia and Middle East countries, but these moneys are given in sympathy for the Bangsamoro cause with no strings attached. ${ }^{125}$

In addition to these donations, the MILF tries other avenues to generate more money. The most notable ones are the collection of Zakāh, Zakätul Fitr, Sadaqah, and remittances that come from the Moro Filipino overseas workers who are members of the United Overseas Bangsamoro. ${ }^{126}$ Reports reveal that MILF collects one million pesos monthly from about 27,000 Muslim overseas workers in the Middle East, and receives about 1.5 million pesos a month from sadaqah. ${ }^{127}$ Further, the Zakātul Fitr that the MILF receives at the end of Ramadān is also a considerable amount.

In addition to these various revenues and donations, MILF also makes use of the vast cultivable land inside its own territory. The area of Camp Abubakar, having almost 5,000 hectares, is good for various agricultural products. In 1998, a fruit nursery was initiated through the MILF-controlled cooperatives with the help of experts from the Central Mindanao Agriculture and Resources Research and Development consortium. ${ }^{128}$ Solar-powered water pumps are employed to help irrigate the farmlands and to cultivate the rice, fruit trees, and vegetables. Other hectares of the land serve as a nursery for seedlings of durian, lanzones, mangosteen, and rambutan. ${ }^{129}$ In Camp Bushra, several thousand hectares are also planted with banana, corn, cassava, coconut, and coffee. In some other camps, like Camp Abu Muthanna, the $114^{\text {th }}$ Base Command of MILF Western Front Command in Basilan, it is none other than the base commander himself who plants various agricultural products, such as coconut, banana and durian. With a background in agricultural engineering, ${ }^{130}$ Musao Abubakar, alias Mujāhid, knows which plants and other agricultural products are suitable to their fertile land.

The MILF of Salamat Hashim is just one of the various groups in Mindanao that seeks justice and freedom from the Christian-dominated government of the Philippines. What is perhaps unique about the MILF is its approach, which is to revive Islam as a whole. MILF is not just an armed group, as it is understood by many, but an organisation that promotes and revives Islam all over Mindanao. 
This distinctive approach became a significant instrument for the group to become the strongest and largest organisation in Mindanao. One obvious sign of approval from the people is the continuation of its appeal even after the demise of Hashim. The most significant effect of this Islamic revivalism is that Islam and jihäd have been revived and planted in the heart of the Bangsamoro people. Shortly after Salamat Hashim's death, he was quoted in a speech, In Memory of Salamat Hashim, delivered before the Muslim Youth Organisation by Soliman Santos who wrote the book, The Moro Islamic Challenge: ${ }^{131}$

This idea (Islamic state) might be viewed as idealistic but I don't mind. What is important is that I believe in it and it is my duty to work for it and I have offered myself to die for it. Whether it is acceptable now or not does not matter. Because I believe a well-founded and deeply studied concept will not die. Only the proponents will die.

Salamat Hashim died without realising his vision, but his $j i h \bar{a} d$ and Islamisation programs continue to dwell in the heart of the Bangsamoro people, as is apparent in the approach of the current leadership of the MILF.

\section{Policy Recommendations}

The researcher recommends one policy to each side: the Philippine government should recognise the legitimate rights of the Moros for self-determination; and Muslim groups should also respect the territorial integrity of the country. The Moros in Mindanao have indicated that they will not stop fighting the government until they are given the freedom of self-determination. On the other hand, the government has also affirmed that it would never allow any group to seek complete independence from the Philippines. Therefore, both sides will have to compromise in order to have lasting peace in Mindanao.

\section{Notes}

* Marjanie S. Macasalong is from Mindanao, Philippines. He obtained his Master's degree in Islamic and Other Civilizations at International Institute of Islamic Thought and Civilization (ISTAC), IIUM-Kuala Lumpur, where he is currently a $\mathrm{PhD}$ candidate. He holds a Bachelor degree in Political Science and his research interest is focused on the socio-political scenario in southern Philippines, Peace and War Studies, Conflict Resolution Studies, Islamic Revivalism, and Rise and Fall of Civilization.

1. Muslims in the Philippines.

2. The term "Philippines" did not exist before the Spaniards came because there was no unified state then in these Islands,; only independent chiefdoms or sultanates. When the Spaniards effectively conquered some part of the Islands, they called it collectively the Phillipines in honour of the king of Spain, King Philip II.

3. Cesar Adib Majul, "The Muslims in the Philippines: An Historical Perspective" in The Muslim Filipinos: Their History, Society and Contemporary Problems, eds. Peter G. Gowing and Robert D. 
McAmis (Manila: Solidaridad Publishing House, 1974), 2.

4. Melvin Mednick, "Some Problems of Moro History and Political Organisation" in The Muslim Filipinos, 13.

5. Peter Gordon Gowing, Muslim Filipinos: Heritage and Horizon, (Quezon City: New Day Publishers, 1979), 15.

6. Cesar Adib Majul, Muslims in the Philippines (Quezon City: University of the Philippines Press, 1973), 63.

7. W. K. Che Man, Muslim Separatism: The Moros of Southern Philippines and the Malays of Southern Thailand (Singapore: Oxford University Press, 1990), 21.

8. Cesar Adib Majul, "Succession in the Old Sulu Sultanate," in The Muslim Filipinos, 63-64.

9. Thomas M. McKenna, Muslim Rulers and Rebels: Everyday Politics and Armed Separatism in the Southern Philippines, (Berkeley: University of California Press, 1998), 50.

10. Datu is the title for the local chief.

11. Cesar Adib Majul, Muslims in the Philippines, 71-72.

12. Peter Gordon Gowing, Muslim Filipinos..., 20-22.

13. Zafra Nicholas, "Matanda, Soliman, Lakandula," Filipino Heritage, Vol. 4. (Manila: Lahing Pilipino Publishing, Inc., 1977), 860.

14. Alunan C. Glang "Modernizing the Muslims" in The Muslim Filipinos, 278-279.

15. Leyte is a province of the Philippines located in the Eastern Visayas region.

16. Salah Jubair, Bangsamoro: A Nation Under Endless Tyranny, (Kuala Lumpur: IQ Marin SDN BHD, 1999), 35.

17. Mactan is an island located a few kilometres from Cebu Island in the Philippines.

18. Salah Jubair, 35 .

19. An island located in the western part of Visayas, Philippines.

20. Salah Jubair, 37.

21. Syed Serajul Islam, The Politics of Islamic Identity in Southeast Asia, (Singapore: Thomson, 2005), 28.

22. A group of fertile, volcanic islands in East Indonesia between Celebes and New Guinea which are very close to the Philippines, most especially Sulu and Mindanao. These areas were the centre of the world spice trade around the $16^{\text {th }}$ century.

23. T. J. S. George, Revolt in Mindanao, (Kuala Lumpur: Oxford University Press, 1980), 50.

24. Syed Serajul Islam, 28.

25. Salah Jubair, 14.

26. Salah Jubair, 38 .

27. Peter Gordong Gowing, Muslim Filipinos..., 29-30.

28. Blair and Robertson, "Account of the Expeditions", Vol. IV, p. 153-154, quoted in Cesar Adib Majul, Muslims in the Philippines, (Quezon City: University of the Philippines Press, 1973), 68.

29. Cesar Adib Majul, Muslims in the Philippines, 81.

30. Lualhati M. Abreu, "Colonialism and Resistance: A Historical Perspective" in The Moro Reader: History and Contemporary Struggles of the Bangsamoro People, ed. Bobby M. Tuazon (Policy Study Publication and Advocacy, Center for People Empowerment in Governance, August 2008), 20.

31. Francisco Jose Diaz (ed.), “The Spanish Declaration of War”, Spanish American War Centennial Website, <http://www.spanamwar.com/declarationwarspain.html $>$ (accessed 23 February 2012).

32. The Spanish-American War Centennial Website, "President McKinley and the Declaration of War", <http://www.spanamwar.com/McKinleywardec.htm> (accessed 23 February 2012).

33. Hispanic Division Library of Congress, "The World of 1898: The Spanish-American War", <http:// www.loc.gov/rr/hispanic/1898/intro.html > (accessed 23 February 2012).

34. Joint Congressional Committee on Inaugural Ceremonies, "Second Inaugural Address of William McKinley on Monday, March 4, 1901", <http://www.bartleby.com/124/pres41.html> (accessed 23 February 2012).

35. Lillian Goldman Law Library, "A treaty of Peace between the United States and Spain", <http:// avalon.law.yale.edu/19th_century/sp1898.asp> (accessed 23 February 2012).

36. T. J. S. George, 52. 
37. Milestone Documents, "Commentary of William McKinley: "Benevolent Assimilation" Proclamation (1898)", <http://www.milestonedocuments.com/documents/view/williammckinleys-benevolent-assimilation-proclamation/explanation> (accessed 23 February 2012).

38. Salah Jubair, 59.

39. Peter Church, A Short History of South-East Asia, 4th ed. (Singapore: John Wiley \& Sons, 2006), 57.

40. Peter Gordon Gowing, Mandate in Moroland: The American Government of Muslim Filipinos 1899-1920, (Quezon City: Community Publishers Inc, 1977), 86-87.

41. Gowing, Mandate in Moroland, 87.

42. The Philippine Independence Act, 1934, (Tydings-McDuffie Law of 1916).

43. Chan Robles Virtual Law Library, "Treaty of General Relations Between the Republic of the Philippines and the United States of America, July 4, 1946, Manila", <http://www.chanrobles.com/ rpustreatyofgeneralrelations.htm (accessed 23 February 2012).

44. Ibid.

45. Public lecture of Abdulwahab M. Amerol, titled So Paninindeg o Bangsamoro [The Fight of the Bangsamoro], Marawi City, p.3.

46. Land Registration Act, 1902 (Act No. 496 of 1902).

47. The Public Land Act, 1919 (Act No. 2874 of 1919).

48. W. K. Che Man, Muslim Separatism: The Moros of Southern Philippines and the Malays of Southern Thailand, (Singapore: Oxford University Press, 1990), 24.

49. W. K. Che Man, 25.

50. Commonwealth Act, 1939 (Act No. 441 of 1939).

51. Ibid.

52. Peter Gordong Gowing, Muslim Filipinos, 176.

53. Republic Act 1160, 1954 (Act No. 1160 of 1954).

54. Ibid.

55. Ibid.

56. Ibid.

57. The Agricultural Land Reform Code, 1971 (Act No. 6389 of 1971).

58. Ibid.

59. Rudy Rodil, "Numbers Can Hurt; Also Wrong Numbers, or No Numbers", MindaNews, 1 May 2011,5 .

60. Rufa Cagoco Guiam, "Retrospect and Prospects: Toward a Peaceful Mindanao", Moro Kurier, no.1 (Jan/March 1996): 4.

61. Public lecture of Abdulwahab Amerol, 4.

62. Salah Jubair, 104.

63. Herbert Docena, "Moro National Liberation", <http://www.revolutionprotestencyclopedia.com/ fragr_image/media/IEO_Moro_national_liberation> (accessed 17 February 2012).

64. Herald Uhlig, "Spontaneous and Planned Settlement in South-East Asia" in Agricultural Expansion and Pioneer Settlements in the Humid Tropics, eds. Walther Manshard and William B. Morgan (Tokyo: The United Nations University, 1988), 24.

65. Ibid.

66. Herald Uhlig, 28.

67. Salah Jubair, 132.

68. Marites D. Vitug \& Glenda M. Gloria, Under the Crescent Moon: Rebellion in Mindanao, (Quezon City: Ateneo Center for Social Policy and Public Affairs, 2000), 4.

69. Sabah is one of the 13 member states of Malaysia and is its easternmost state. It is located on the northern portion of the island of Borneo.

70. Cesar Adib Majul, The Contemporary Muslim Movement in the Philippines, (Berkeley: Mizan Press, 1985), 40.

71. Salah Jubair, 132.

72. Marites \& Glenda, 2,

73. Ibid.

74. Macapado Abaton Muslim, The Moro Armed Struggle in the Philippines: The Nonviolent Autonomy 
Alternative (Mindanao State University: University Press and Information Office, 1994), 93.

75. Marites \& Glenda, 22.

76. Ibid., 3 .

77. One of the major Filipino dialects in the Philippines.

78. Cesar Adib Majul, The Contemporary Muslim Movement in the Philippines, 50.

79. Raqs-Special Features, 15 September 2007, <http://raqs-specialfeatures.blogspot.com/2007/09/ memories-of-manili-massacre.html $>$ (accessed 6 February 2012).

80. Ibid.

81. Jovi, one of the victims of the ILAGA-related massacres, interview by the author, Camp Bushra, Butig, 29 January 2012.

82. Salah Jubair, 138-139.

83. Philippine Sunday Express, 24 September 1972, 17.

84. Salah Jubair, 139.

85. T. J. S. George, 149.

86. Salipada K. Pendatun, "Is There a Design to Wipe Out the Muslims in the Philippines?" A Speech Delivered at the House of Representatives, Congress of the Philippines, 1971 and Reprinted by the Ansar El Islam on the Occasion of its $2^{\text {nd }}$ National Islamic Symposium and $3^{\text {rd }}$ Foundation Anniversary, Marawi City, April 28-May 1, 1972.

87. Cesar Adib Majul, The Contemporary Muslim Movement in the Philippines, 52.

88. Salah Jubair, 154.

89. The two leaders have different educational background. Salamat Hashim finished his Islamic studies at Al-Azhar University, Egypt. This particular background shaped Hashim to become Islamic-oriented. Nur Misuari is usually referred to as secular-oriented for he finished his study in Political Science at the University of the Philippines. As shown from the discussion above, the two leaders have different goals should their organisation succeed. Nur Misuari's goal is to liberate the Moroland from the yoke of oppression with a democratic type of governance. In some accounts, it was reported that Misuari had aligned himself with the communists in the country. For Hashim, it is not only to liberate the Moroland and have freedom; rather what is more important is to have an Islamic state where Sharia can be the rule. Thus these two leaders are identified based on their orientation and goal. As to leadership style, Misuari was said to have monopolized the decisionmaking in the MNLF, while Hashim was following a collective-type of decision-making in the MILF.

90. Salah Jubair, 154.

91. Michael O. Mastura, Bangsamoro Quest: The Birth of the Moro Islamic Liberation Front, (Malaysia: SEACSN and REPUSM, 2012), 39.

92. Letter of Salamat Hashim to OIC Secretary General Ahmadou Karim Gaye dated 23 December 1977.

93. Salah Jubair, 155.

94. Salamat Hashim, The Bangsamoro Mujahid: His Objectives and Responsibilities, (Mindanao: Bangsamoro Publications, 1985), 4.

95. Salamat Hashim, The Bangsamoro Mujahid, 8-9.

96. Abhoud Syed Mansur Lingga, "The Political Thought of Salamat Hashim", (M.A. Thesis, University of the Philippines, 1995), 26.

97. International Crisis Group, "Southern Philippines Backgrounder: Terrorism and the Peace Process," International Crisis Group Asai Report No. 80, 13 July 2004, 3.

98. Francisco Cruz Jr., "Morojihad and the Islamic Vision of Ustadz Salamat Hashim: Understanding MILF's Politico-Religious Ideology", Philippine Institute for Political Violence and Terrorism Research, (August 2008): 1.

99. Francisco Cruz Jr., 7-8.

100. Joseph Chinyong Liow, "Muslim Resistance in Southern Thaniland and Southern Philippines: Religion, Ideology, and Politics", East-West Center Washington, Policy Studies 24 (2006): 15.

101. Salamat Hashim, 1.

102. Lualhati M. Abreu, "The Bangsamoro Ancestral Domain: The Bangsamoro Continuing Past Anchored on Customary Adat and Islamic Thinking", in The Mindanao Conflict, eds. Kamaruzaman 
Askandar and Ayesah Abubakar (Malaysia: The Southeast Asian Conflict Studies Network Publications, 2005), 110.

103. Islamic school

104. The meaning of Mujahideen in this article is "Muslim fighters".

105. Aleem Abdul Aziz Mimbantas, Vice-Chairman for Military Affairs, Central Committee of the Moro Islamic Liberation Front, interview by the author, Camp Bushra, 28 January 2012.

106. Marites \& Glenda, 109 .

107. Ibid.

108. Abdullah Macapaar, the Front Commander of North Western Mindanao Front, interview by the author, Wato, 1 February 2012.

109. Commonly defined as an interest-based transaction.

110. Al Haj Murad, Jihad in Defense of Islam and the Bangsamoro People, (Mindanao: Agency for Youth Affairs - MILF, 2006), 46.

111. Bin Masdidah Mimbantas, $2^{\text {nd }}$ in command of the Bismillah Operation, interview by the author, Camp Bushra, 28 January 2012.

112. Mitch Mimbantas, accomplice of the Bismillah Operation, interview by the author, Camp Bushra, 28 January 2012.

113. Francisco Cruz Jr., 8.

114. Peter Chalk, "Separatism and Southeast Asia: The Islamic Factor in Southern Thailand, Mindanao and Ache", Studies in Conflict and Terrorism, vol. 24 (2001): 241-269.

115. Ismael G. Kulat, GRP-MILF peace talks: Its implication to the Bangsamoro Struggle for Right to Self-Determination (Cotabato City: Consortium of Bangsamoro Civil Society, Inc., n.d.), 6.

116. Joseph Chinyong Liow, 13.

117. Shamsuddin L. Taya, "The Political Strategies of the Moro Islamic Liberation Front for SelfDetermination in the Philippines," Intellectual Discourse, vol. 15, no. 1 (2007): 66.

118. Salamat Hashim died on 13 July 2003 at Camp Bushra from sudden cardiac arrest. He was subsequently replaced by the current chairman, Al Haj Murad Ibrahim.

119. Salamat Hashim, 12-13.

120. In this article, jihâd refers to armed struggle.

121. Marites \& Glenda, 110.

122. Oshama Bin Ali, Director General of Salamat Hashim Islamic Memorial Military Academy (SHIMMA), interview by the author, Dārul Imān, satellite camp of Camp Bushra, 29 January 2012.

123. Salamat Hashim, 41-42.

124. Ibid.

125. Soliman, M. Santos, Jr. \& Paz Verdades M. Santos, Primed and Purposeful: Armed Groups and Human Security Efforts in the Philippines (Switzerland: Small Arms Survey, 2010), 349.

126. Soliman, M. Santos, Jr. \& Paz Verdades M. Santos, 347.

127. Francisco Cruz Jr., 10.

128. Marites \& Gloria, 108.

129. Ibid.

130. Musao Abubakar, alias Mujahid, Commander of 114 Base Command of MILF Western Front, interview by the author, Camp Muthanna, Basilan, 2 February 2012.

131. Francisco Cruz, Jr., 13. 